\author{
Natalia Lubaśa \\ (D) https://orcid.org/0000-0001-5936-7200
}

\title{
Umowy dotyczące spadku obejmującego przedsięhiorstwo rodzinne na przykładzie rozwiązań hiszpańskich
}

\begin{abstract}
The present article addresses the issues relating to the agreements as to family business succession with a particular focus on the Catalan law pertaining thereto. The paper first identifies certain general difficulties that result from lack of official „family business" definition, both at the national and international levels. Then, briefly explains the specificity of the Spanish legal system, that is particularly visible from the perspective of inheritance law, the systems of which Spain has as many as seven, including Catalan, which is of particular interest in the present article. The paper then moves to the family protocol - an institution whose task is to fully and comprehensively assist family enterprises in arranging both internal and external relations with third parties. Then the special attention is devoted to the heretament and pacte successori d'atribució particular as examples of succession agreements in Catalan law. The admissibility of the succession agreements, as discussed by the author, is closely related to the continuity of family businesses. It is considered an appropriate measure to guarantee their integrity and intergenerational transfer. Therefore the author suggests that the Polish legislator should not cease looking for institutions that would support entrepreneurs in the process of inheritance planning.
\end{abstract}

Keywords: family business succession — dispositions upon death - agreements as to succession — Spanish law - Catalan law — heredamiento — family protoco

a) Mgr, Akademia Leona Koźmińskiego w Warszawie, doktorantka w Katedrze Prawa Cywilnego. 


\section{Wstęp}

W państwach, których prawo zakazuje lub znacznie ogranicza zawieranie umów dziedziczenia, podejmuje się różne próby przełamania tych zakazów lub ograniczeń w odniesieniu do przedsiębiorstw rodzinnych.

Próby podjęte we Włoszech ${ }^{1}$ oraz we Francji ${ }^{2}$ zostały już omówione w naszym piśmiennictwie. W dalszych rozważaniach zostanie podjęta próba zarysowania zmian, jakie w rozważanym zakresie wprowadzono w Hiszpanii, w tym zwłaszcza w Katalonii.

Wybór Hiszpanii, a w szczególności prawa katalońskiego, nie został dokonany przypadkowo. Katalonia jest regionem o bardzo ugruntowanej i wieloletniej tradycji przedsiębiorstw rodzinnych. Najstarsze hiszpańskie przedsiębiorstwo rodzinne to Codorniu Raventós, kataloński producent win musujących, którego początki datowane są na rok 1551, a w czołówce najstarszych hiszpańskich przedsiębiorstw rodzinnych największą grupę stanowią przedsiębiorstwa katalońskie.

W czasach, gdy tylko ok. $10-15 \%$ przedsiębiorstw rodzinnych udaje się przekazać trzeciemu pokoleniu, przykład kataloński jest znakomitym wzorcem wsparcia przedsiębiorców w procesie kształtowania międzypokoleniowego przekazywania własności przedsiębiorstw, będących owocem wieloletnich starań całych rodzin. Szczególnym przykładem jest mocno zakorzeniona historycznie katalońska dbałość o wspólne dobro rodzinne - casa, dawniej rozumiane jako całokształt majątku rodzinnego (patrimonio familiar), w przeszłości stanowiące głównie gospodarstwo rolne, a dziś przede wszystkim przedsiębiorstwo rodzinne. Dzięki

${ }^{1}$ Szerzej na ten temat: P. Blajer, Umowa o spadek jako narzędzie zmian generacyjnych $w$ rolnictwie - na przyktadzie wtoskiej instytucji „patto di famiglia”, „Kwartalnik Prawa Prywatnego" 2011, z. 2, s. 435-506; C. Caccavale, Divieto dei patti successori ed attualità degli interessi tutelati. Appunti per uno studio sul Patto di famiglia: profili strutturali e funzionali della fattispecie, https://elibrary.fondazionenotariato.it/articolo.asp?art=02/0203\&mn=3 [Dostęp: 20.09.2021 r.]; M. Ieva, Il patto di famiglia, in: P. Rescigno, M. Ieva, Trattato breve delle successioni e donazioni, CEDAM, 2010, s. 317347; G. Petrelli, La nuova disciplina del patto di famiglia, „Rivista del Notariato” 2006, $\mathrm{N}^{\circ} 60$, s. 401-466.

2 Szerzej na ten temat: K. Górniak, Mandat na wypadek śmierci $w$ prawie francuskim, „Kwartalnik Prawa Prywatnego” 2019, z. 4, s. 919-939; J. Pazdan, Umowy rodzinne o skutkach spadkowych na tle rozporzadzenia Nr 650/2012, w: Kolizyjne i procesowe aspekty prawa rodzinnego, red. J. Gołaczyński, W. Popiołek, C.H. Beck, Warszawa, 2019, s. 124; S. Ferré-André, Le droit français du mandat à effet posthume, une innovation attendue de la loi du 23 juin 2006, „La Revue du Notariat” [Montréal] 2009, vol. 111, s. 381-391; F. Guillame, A.-S. Papeil, Transmission d'une entreprise familiale à un descendant: essai comparatif Suisse-France, „Semaine judiciaire” 2009, No 2, s. 33-75. 
odpowiednim regulacjom prawnym wychodzącym naprzeciw oczekiwaniom przedsiębiorców Katalonia stała się jednym z najbogatszych regionów Europy, charakteryzujących się ciągłym rozkwitem gospodarczym ${ }^{3}$.

W polskim prawie spadkowym ustawodawca przez wiele lat troszczył się głównie o losy gospodarstw rolnych, kierowany różnymi pobudkami - bądź to nacjonalizacyjnymi, bądź też ekonomiczno-społeczny$\mathrm{mi}^{4}$. Nie widział natomiast potrzeby wprowadzania przepisów, które mogłyby ułatwić ochronę przedsiębiorstw i wsparcie ich właścicieli w procesie kształtowania sukcesji. Owszem, wprowadzenie w $2011 \mathrm{r}^{5}$ instytucji zapisu windykacyjnego zdecydowanie ułatwiło międzypokoleniowy proces przekazywania przedsiębiorstw rodzinnych, m.in. przesądzając $\mathrm{w}$ art. $981^{1} \S 2$ k.c., że przedmiotem zapisu windykacyjnego może być zarówno gospodarstwo rolne, jak i przedsiębiorstwo, czy też umożliwiając w art. $986^{1}$ k.c. powołanie wykonawcy testamentu do sprawowania zarządu spadkiem, jego zorganizowaną częścią lub oznaczonym składnikiem, a tym samym do zarządu przedsiębiorstwem ${ }^{6}$. W literaturze rozważano także szereg propozycji dotyczących wprowadzenia do naszego prawa innych instrumentów ${ }^{7}$, które mogłyby pomóc w zachowaniu funkcjonowania przedsiębiorstwa i jego przekazywania kolejnym pokoleniom.

W roku $2018^{8}$, niejako jako zwieńczenie tych poszukiwań, pojawił się nowy instrument, mający na celu ochronę przedsiębiorstwa na wypadek

${ }^{3}$ F.J. Olmedo Castañeda, Prohibición de los pactos sucesorios en el Derecho común: cuestionamento de su ratio legis. Propuesta para su admisibilidad, „Anuarion de Derecho Civil" 2019, vol. 72, fasc. II, s. 471.

${ }^{4}$ M. Pazdan, Zarzad sukcesyjny - aspekty kolizyjnoprawne, w: Prawo handlowe. Między teoria, praktyka a orzecznictwem. Księga jubileuszowa dedykowana Profesorowi Januszowi A. Strzępce, red. P. Pinior, P. Relidzyński, W. Wyrzykowski, E. Zielińska, M. Żaba, C.H. Beck, Warszawa, 2019, https://sip.legalis.pl/document-full.seam?documentId=mjxw62zogi3damrtgmydqna [Dostęp: 20.09.2021 r.].

${ }^{5}$ Ustawa z dnia 18 marca 2011 r. o zmianie ustawy - Kodeks cywilny oraz niektórych innych ustaw, Dz.U. 2011, nr 85, poz. 458.

${ }^{6}$ Szerzej na temat relacji wykonawcy testamentu a zarządcy sukcesyjnego M. Pazdan, Zarzadca sukcesyjny a wykonawca testamentu, w: „Ius est ars boni et aequi”. Księga pamiatkowa dedykowana Profesorowi Józefowi Frackowiakowi, red. A. Dańko-Roesler, M. Leśniak, M. Skory, B. Sołtys, Wolters Kluwer, Wrocław, 2018, s. 885-894; M. Pazdan, O rozgraniczaniu statutów i wsysaniu regulacji prawnej (na przykładzie prawa stosowanego do oceny różnych aspektów powołania $i$ funkcjonowania wykonawcy testamentu $i$ zarzadcy sukcesyjnego przedsiębiorstwem), „Problemy Prawa Prywatnego Międzynarodowego" 2020, T. 27, s. 159-177.

${ }^{7}$ Szerzej na ten temat - M. Pazdan, Zarzad sukcesyjny..., a także podana tam literatura.

${ }^{8}$ Ustawa z dnia 5 lipca 2018 r. o zarządzie sukcesyjnym przedsiębiorstwa osoby fizycznej, Dz.U. 2018, poz. 1629. 
śmierci, a mianowicie zarząd sukcesyjny. Instytucja ta, wszechstronnie analizowana w literaturze ${ }^{9}$, ma jednak dość ograniczony zasięg, jako że dotyczy jedynie przedsiębiorców zarejestrowanych w Centralnej Ewidencji i Informacji o Działalności Gospodarczej, a ponadto jest ograniczona w czasie, co przy przewlekłości postępowań spadkowych, a często i skłóceniu potencjalnych spadkobierców, jest niewystarczające do usprawnienia płynnego i nieobarczonego szkodami przejścia przedsiębiorstwa „z rąk do rąk".

Polski ustawodawca nie powinien ustawać w poszukiwaniach instytucji, które wspomogą przedsiębiorców w jakże trudnym procesie planowania dziedziczenia i zmian międzypokoleniowych, a także starać się rozwiązać ten problem w sposób jak najpełniejszy. Poszukiwania te może ułatwić znajomość obcych rozwiązań.

\section{Przedsięhiorstwo rodzinne — próba definicji}

Olbrzymia, a nawet przeważająca większość przedsiębiorstw nie tylko na terenie Europy, lecz również na obszarze całego świata to przedsiębiorstwa rodzinne. Zgodnie z danymi przedstawionymi przez European Family Businesses ${ }^{10}$, przedsiębiorstwa te generują ok. $60-90 \%$ światowego pozarządowego PKB, zapewniają ok. 50-80\% wszystkich miejsc pracy $\mathrm{w}$ sektorze prywatnym, ok. $85 \%$ start-upów rozpoczyna działalność przy użyciu środków pochodzących z budżetów rodzinnych, a w większości krajów na świecie przedsiębiorstwa rodzinne stanowią $70-95 \%$ wszystkich podmiotów gospodarczych.

W Hiszpanii, która jest punktem odniesienia niniejszych rozważań, przedsiębiorstwa rodzinne stanowią aż $85 \%$ przedsiębiorstw hiszpańskich i generują 70\% zatrudnienia w sektorze prywatnym oraz produktu krajowego brutto ${ }^{11}$.

9 J. Bieluk, Zarzadca sukcesyjny - nowa instytucja $w$ polskim prawie spadkowym, „Białostockie Studia Prawnicze” 2017, vol. 22, nr 4, s. 47-57; R. Blicharz, Ustanowienie zarzadu sukcesyjnego przedsiębiorstwem osoby fizycznej po jej śmierci, w: Prawo handlowe. Między teoria, praktyka a orzecznictwem..., red. P. Pinior, P. Relidzyński, W. Wyrzykowski, E. Zielińska, M. Żaba; M. Pazdan, Zarzad sukcesyjny...; M. Pazdan, Zarzadca sukcesyjny..., s. 885-894; M. Pazdan, O rozgraniczaniu statutów..., s. $159-177$.

${ }^{10} \mathrm{https} / / / \mathrm{www}$. europeanfamilybusinesses.eu/uploads/Modules/Publications/familybusiness-statistics.pdf [Dostęp: 8.06.2021 r.].

${ }^{11}$ F.J. Olmedo Castañeda, Prohibición de los pactos sucesorios..., s. 456. 
W hiszpańskim systemie prawnym brak jest ustawowej definicji przedsiębiorstwa rodzinnego (empresa familiar). W preambule do dekretu królewskiego $\mathrm{nr} 171 / 2007^{12}$ ustawodawca stwierdza, że są to przedsiębiorstwa, w których własność lub uprawnienia decyzyjne należą całkowicie lub częściowo do grupy osób, które są spokrewnione lub spowinowacone. Koncepcja ta zbiega się z charakterystyką tego typu przedsiębiorstw, dokonaną przez Senat w 2001 r., który mimo przyznania, że nie ma powszechnego konsensusu co do tego, czym jest przedsiębiorstwo rodzinne, wskazał na następujące cechy definiujące: 1) jedna rodzina (jeśli jest to przedsiębiorstwo jednorodzinne) posiada znaczny udział w zasobach kapitału; 2) na podstawie w/w udziału rodzina ta może sprawować kontrolę nad spółką; 3) rodzina uczestniczy w zarządzaniu, stanowiąc (w spółkach korporacyjnych) całość lub większość zarządu spół$\mathrm{ki}$; 4) pragnienie rodziny, aby przedsiębiorstwo trwało w czasie, tym samym własność, zarządzanie lub kierownictwo przenoszone są na kolejne pokolenia ${ }^{13}$.

Ze względu na specyficzną tożsamość i wartości, którymi charakteryzują się te przedsiębiorstwa, wymagają one szczególnych regulacji prawnych ułatwiających ich dziedziczenie zarówno w sferze zarządzania, jak i przenoszenia „własności”.

Trudności w zdefiniowaniu pojęcia „przedsiębiorstwa rodzinne” wynikają także $\mathrm{z}$ zaangażowania $\mathrm{w}$ badanie tych podmiotów wielu dyscyplin naukowych, takich jak: ekonomia, prawo, finanse, socjologia, zarządzanie, rachunkowość, jak również antropologia czy psychologia.

\section{Specyfika hiszpańskiego i katalońskiego systemu prawnego}

Hiszpania posiada siedem systemów prawa spadkowego o zróżnicowanych cechach i dość odmiennych instytucjach. Hiszpański kodeks cywilny [dalej: h.k.c.] ${ }^{14}$ pochodzi z 1889 r., jednak jego kodyfikacja nie doprowadziła do całkowitej unifikacji prawa prywatnego. Księdze Trzeciej, Tytuł III hiszpańskiego kodeksu cywilnego z 1889 r., który zawiera 331 artykułów dotyczących spadków (art. 657-1087), towarzy-

12 „Boletín Oficial del Estado” [dalej: BOE], N 65, z dnia 16 marca 2007, s. 11254.

13 J. Egea Fernández, Protocolo familiar y pactos sucesorios. La proyectada reforma de los heredamientos, InDret 2007, $\mathrm{N}^{\circ} 3$, s. 9.

${ }_{14}$ Dekret królewski z dnia 24 lipca 1889 r., „Gaceta de Madrid” No 206, de 25/07/1889, BOE-A-1889-4763. 
szą przepisy cywilnoprawne sześciu wspólnot autonomicznych. Artykuł 149 ust. 1 pkt 8 Konstytucji Hiszpanii ${ }^{15}$ przewiduje, że do wyłącznej kompetencji państwa należy m.in. „ustawodawstwo cywilne, bez uszczerbku dla zachowania, zmiany i rozwijania przez wspólnoty autonomiczne praw cywilnych, dawnych rad wspólnot ${ }^{16}$ lub specjalnych, tam gdzie one istnieją. W każdym wypadku zasady odnoszące się do stosowania i skuteczności norm prawnych, stosunki cywilnoprawne dotyczące form małżeństwa, systemu rejestrów i dokumentów publicznych, podstawy zobowiązań umownych, normy rozstrzygające kolizję ustaw oraz określenie źródeł prawa, z poszanowaniem, w tym ostatnim wypadku, norm dawnego prawa rad wspólnot lub specjalnego". W ogólnej strukturze wspomnianych autonomicznych wspólnotowych praw cywilnych (derechos forales) ${ }^{17}$ prawo spadkowe zwykle stanowi ich największą częśśc ${ }^{18}$.

Należy podkreślić, że specyfika hiszpańskiego prawa prywatnego (w tym interesującego nas prawa spadkowego) polega na tym, że na wskazanych terytoriach ${ }^{19}$ hiszpański kodeks cywilny występuje jedynie jako prawo uzupełniające, w przypadku braku przepisów szczególnych odpowiednich wspólnot. Ciekawą kwestią jest również rozstrzyganie kolizji interregionalnych. Zgodnie z art. 16 ust. 1 h.k.c. zastosowanie mają normy kolizyjne prawa prywatnego międzynarodowego, a w szczególności, w odniesieniu do interesujących nas spraw spadkowych, art. 9 ust. 8 h.k.c. ${ }^{20}$

Jedną z cech specyficznych hiszpańskiego (ale również m.in. katalońskiego) prawa spadkowego jest tzw. legítima - część spadku, którą testator nie może rozporządzać (rodzaj rezerwy spadkowej). Pomimo wielu głosów w doktrynie opowiadających się wręcz za nieprzystawalnością tejże instytucji do dzisiejszych czasów, wciąż dzierży ona silną pozycję wśród przepisów prawa spadkowego. Nawet w tak „liberalnym” systemie prawa spadkowego, jak kataloński, nadal wszelkie rozrządzenia zamieszczone w umowie spadkowej dokonane przed śmiercią przyszłego spadkodawcy,

15 BOE N 311 z dnia 29 grudnia 1978 r., BOE-A-1978-31229 [tekst jedn.], tekst polski — https://biblioteka.sejm.gov.pl/wp-content/uploads/2015/10/Hiszpania_pol_300612.pdf [Dostęp: 20.09.2021 r.].

${ }_{16} \mathrm{~W}$ oryginale forales.

17 Bardziej szczegółowe informacje na ten temat podaje J. Krysa, Niejednolitość terytorialna prawa hiszpańskiego a prawo prywatne międzynarodowe, „Problemy Prawa Prywatnego Międzynarodowego" 2014, T. 14, s. 24 i n.

18 S. Cámara Lapuente, New developments in the Spanish Law of Succession, InDret $2007, \mathrm{~N}^{\circ} 4$, s. 4.

${ }^{19}$ Katalonia, Bizkaia i Álava, Baleary, Galicja, Aragonia oraz Nawarra.

${ }^{20}$ Bardziej szczegółowe rozważania na ten temat: J. Pazdan, Umowy dotyczqce spadku w rozporzadzeniu spadkowym Unii Europejskiej, C.H. Beck, Warszawa, 2018, s. 37 i n. 
które pociągają za sobą zrzeczenie się prawa do legítima lub naruszają jego treść, są nieważne ${ }^{21}$. Istnieją jednak wyjątki od tej reguły w sposób enumeratywny wymienione w art. 451-26 ust. 2 katalońskiego kodeksu cywilnego [dalej: k.k.c. ${ }^{22}$.

W preambule do ustawy nowelizującej czwartą księgę katalońskiego kodeksu cywilnego ustawodawca wymienia zasady katalońskiego prawa spadkowego, które odróżniają je od wielu innych systemów prawnych, i w jego mniemaniu sprawdziły się dość dobrze w praktyce spadkowej, dlatego ich zmiana nie została uznana za właściwą. Jednakże, jak zaznaczono w preambule, ten sam system ustanawia, gdy istnieją powody, które to uzasadniają, odpowiednie wyjątki lub modyfikacje ${ }^{23}$. Mowa tu o zasadach: konieczności powołania spadkobiercy (de necesidad de heredero), uniwersalności tytułu powołania spadkobiercy (de universalidad del título de heredero), niepodzielności tytułu dziedziczenia (de incompatibilidad de títulos sucesorios - nemo pro parte testatus pro parte intestatus decedere potest $)^{24}$, bezwarunkowego i bezterminowego nabycia spadku (de perdurabilidad del título sucesorio - semel heres semper heres) ${ }^{25}$ oraz pierwszeństwa tytułu dobrowolnego (prevalencia del título voluntario $)^{26}$.

O ile cztery pierwsze wymienione zasady w sposób oczywisty można określić jako wywodzące się z prawa rzymskiego, o tyle piąta zasada może być traktowana jako preludium heretament, instytucji specyficznej

${ }^{21}$ Art. 451-26 katalońskiego kodeksu cywilnego - BOE No 190 z dnia 7 sierpnia 2008 r., s. $33735-33788$.

${ }^{22}$ Są to umowy między małżonkami lub konkubentami pozostającymi w stałym związku partnerskim, w których zrzekają się prawa do legítima, które mogłoby im przysługiwać po wspólnych dzieciach, bądź umowy między dziećmi a rodzicami, w których ci ostatni zrzekają się prawa do legítima, które mogłoby im przysługiwać po dzieciach albo zawarte między wstępnymi i zstępnymi w umowie dotyczącej dziedziczenia lub darowizny, na mocy której zstępny, który otrzymuje dobra lub pieniądze od swojego wstępnego w zamian za legítima, zrzeka się ewentualnego jego uzupełnienia — z zastrzeżeniem, że zostaną one zawarte $\mathrm{w}$ formie aktu notarialnego.

${ }^{23} \mathrm{BOE} \mathrm{N}^{\circ} 190$ z dnia 7 sierpnia 2008 r., s. 33735.

${ }^{24} \mathrm{~W}$ prawie katalońskim, w przeciwieństwie do zasad prawa hiszpańskiego, wola przyszłego spadkodawcy jest zawsze uprzywilejowana w odniesieniu do spadku nieobjętego treścią testamentu. Ponadto dopuszczalne jest podstawienie pospolite, pupilarne, quasi-pupilarne (wywodzące się z tradycji prawa rzymskiego) lub przykładowe (ejemplar). W przypadku braku substytuta lub bezskutecznego jego ustanowienia dochodzi do ius adcrescendi pomiędzy pozostałymi współspadkobiercami; tematyka ta jednak wymagałaby szerszego opracowania i wykracza poza ramy niniejszego artykułu.

${ }^{25}$ Choć w prawie katalońskim istnieje wyjątek od tej zasady, jako że dopuszcza ono fideikomis warunkowy (fideicomiso condicional).

${ }^{26}$ Ustawodawca kataloński jako źródła powołania do spadku faworyzuje umowę powołania spadkobiercy (heretament), a następnie testament, dając $\mathrm{w}$ ten sposób prymat woli spadkodawcy, na ostatnim miejscu zaś umieszcza ustawę. 
dla prawa katalońskiego, o której będzie mowa poniżej, jako że zakłada przyznanie statusu spadkobiercy za życia przyszłego spadkodawcy; tym samym jest więc obca prawu rzymskiemu, które co do zasady nie dopuszczało dziedziczenia umownego ${ }^{27}$.

\section{Protokół rodzinny: Rodzinna umowa ramowa?}

Formalne porozumienie członków rodziny, umowa ramowa, swoisty kodeks postępowania, a nawet zbiór idei (ideario) lub filozofii ${ }^{28}$ przedsiębiorstwa rodzinnego - to przykłady prób zdefiniowania protokołu rodzinnego. Ustawodawca hiszpański dekretem królewskim nr 171/200729 z dnia 9 lutego 2007 r. po raz pierwszy zdefiniował w art. 2 instrument stosowany od wielu lat $\mathrm{w}$ Hiszpanii, a mianowicie protokół rodzinny (el protocolo familiar $^{30}$ ). Jest to instytucja, która w pełny, wszechstronny sposób ma pomagać przedsiębiorstwom rodzinnym w układaniu zarówno stosunków wewnętrznych, jak i zewnętrznych z podmiotami trzecimi, m.in. na płaszczyznach prawnej, ekonomicznej, podatkowej czy biznesowej. To swoisty zbiór dokumentów, umów, porozumień zawartych między partnerami/wspólnikami lub z osobami trzecimi, z którymi łączą ich więzi rodzinne, w odniesieniu do spółki nienotowanej na giełdzie, a ich wspólnym celem jest osiągnięcie modelu komunikacji i konsensusu $\mathrm{w}$ procesie decyzyjnym regulującym relacje między rodziną, majątkiem i przedsiębiorstwem, które mają wpływ na dany podmiot ${ }^{31}$. Zarówno aspekt podmiotowy, przedmiotowy, jak i formalny protokołu nie stały się przedmiotem regulacji wyżej wspomnianego dekretu, podobnie jak jego treść, która podlega zasadzie swobody umów, ograniczonej przepisami o charakterze ogólnym, zarówno prawa cywilnego (jak np. art. 1255 h.k.c. dotyczący zasady swobody umów), jak i prawa spółek.

27 C. Tort-Martorell, Sobre el heredamiento como excepción a los principios romanos de derecho sucesorio en el vigente código civil de Cataluña, „Fundamina. A Journal of Legal History" 2014, No 20 (2), s. 925-926.

28 J. Egea Fernández, Protocolo familiar y pactos sucesorios..., s. 5.

${ }^{29} \mathrm{BOE} \mathrm{N}^{\mathrm{o}} 65$, z dnia 16 marca 2007, s. 11254-11257.

30 Tłumaczone także jako „rejestr rodzinny”, co w mojej opinii nie uwzględnia istoty tejże instytucji (tak m.in. https://eur-lex.europa.eu/legal-content/PL-ES/ $\mathrm{TXT} /$ ?from=ES\&uri=CELEX\%3A52006XC0104\%2803\%29\&qid=1623141710578) [Dostęp: 20.09.2021 r.].

31 Tłumaczenie - Preambuła do dekretu królewskiego nr 171/2007 - BOE N 65 , z dnia 16 marca 2007, s. 11254. 
Wspomniany dekret miał skonsolidować stan prawny przedsiębiorstw należących do osób powiązanych więzami rodzinnymi, jako istotnego elementu struktury ekonomicznej krajów rozwiniętych, a także jako odzwierciedlenie specyficznych okoliczności, które warunkują rozwój i trwałość takich przedsiębiorstw. Ustawodawca hiszpański, dla szerszego zastosowania tegoż protokołu w praktyce, wprowadził wiele możliwości rejestracji, o różnym zasięgu, zawsze jednak mających charakter dobrowolny (co podkreśla art. 2 ust. 3 wspomnianego dekretu), ze względu na poufną specyfikę większości postanowień takiego protokołu.

Swoistym pierwowzorem protokołu rodzinnego jest shareholders agreement (który pojawił się w Stanach Zjednoczonych w latach sześćdziesiątych XX w.), sankcjonowany w praktykach zarządczych spółek rodzinnych zwłaszcza w krajach anglosaskich, w których uważany jest za dodatkową gwarancję dla osób trzecich, inwestorów i wierzycieli, a dodatkowo dla samych partnerów/wspólników, zapewniając przewidywalność zmian pokoleniowych w przedsiębiorstwie.

Treść protokołu może być bardzo niejednorodna, może bowiem łączyć w sobie zwykłe deklaracje dobrych intencji (mało istotne z prawnego punktu widzenia, możliwe do wyegzekwowania jedynie z punktu widzenia moralnego - tzw. el pacto entre caballeros) z umowami zawartymi przez członków rodziny, zarówno w formie dokumentu publicznego, jak i prywatnego (ze skutkiem inter partes - el protocolo contractual), a nawet $\mathrm{z}$ innymi postanowieniami (jak te, które wpływają na status prawny akcji lub udziałów czy porozumień dotyczących głosowania), które zwykle są już włączone do statutu/umowy spółki i są skuteczne wobec osób trzecich (el protocolo institucional) ${ }^{32}$.

Treść protokołu zawiera co do zasady klauzule związane z prawami i obowiązkami członków rodziny, którzy go podpisują (wynagrodzenie, standardy kwalifikacji zawodowych, wstąpienie do przedsiębiorstwa i wystąpienie $z$ niego, organizacja rodzinna i spadkowa, umowy przeniesienia udziałów/akcji itp.). Dlatego, jeżeli ogólne warunki umowy są spełnione, osoby, które wyrażą zgodę na podpisanie protokołu o określonej treści, są związane umową, przy zastosowaniu w każdym przypadku ogólnych zasad wykonywania zobowiązań umownych.

Stwierdzenie, że umowna część protokołu ma charakter nietypowej umowy wielostronnej i jest skuteczna inter partes nie jest sprzeczne $\mathrm{z}$ faktem, że protokołowi rodzinnemu przypisuje się również charakter organizacyjny lub umowy ramowej, której określone postanowie-

32 A.S. Fernández-Sancho Tahoces, La sucesión en la empresa familiar: el protocolo familiar y su publicidad registral, „Revista Aranzadi de derecho patrimonial” 2009, $\mathrm{N}^{\circ} 23$, s. 289. 
nia wymagają późniejszego opracowania lub wykonania w celu nadania skuteczności jego treści - zwłaszcza, że może dotyczyć osób trzecich. W zależności od przypadku efekt taki jest osiągany przez same statuty/umowy spółek lub umowy pozastatutowe czy też umowy wspólników, a przede wszystkim umowy majątkowe małżeńskie, testamenty lub umowy dziedziczenia zawierane z członkami rodziny.

Należy wziąć pod uwagę, że protokół rodzinny jest dokumentem „prawnie niekompletnym” ${ }^{33}$, który dla uzupełnienia wymaga sporządzenia testamentu, zawarcia umowy majątkowej małżeńskiej czy też określonych umów między wspólnikami/„współwłaścicielami” przedsiębiorstwa. Dlatego też jeśli protokół przewiduje, że członków rodziny obowiązuje określony ustrój majątkowy małżeński, aby uniknąć szkodliwych skutków ustania wspólności majątkowej małżeńskiej członka spółki, umowna część protokołu zakłada, że zobowiązanie musi być skonkretyzowane w umowie majątkowej małżeńskiej przez każdego z członków, co jest niezależne od skuteczności inter partes umownej części protokołu i odpowiedzialności członków rodziny za niewykonanie zaciągniętych zobowiązań ${ }^{34}$.

Jeśli chodzi natomiast o testamenty, należy podkreślić, że mając na uwadze wyrażony przez ustawodawcę hiszpańskiego w art. 737 h.k.c. zakaz ograniczeń swobody testowania, jakiekolwiek zapisy zamieszczone w protokole rodzinnym zmierzające do zobowiązania przyszłego testatora do sporządzenia testamentu o określonej treści lub do jego nieodwoływania $^{35}$ są bezskuteczne. Swoboda testowania jest szczególnie chroniona w systemie hiszpańskiego prawa spadkowego i nie może stać się przedmiotem zrzeczenia, umowy lub ograniczenia. Dlatego też ze względu na jedną z najbardziej specyficznych cech testamentu, jaką jest każdorazowa możliwość jego odwołania, jego sporządzenie nie gwarantuje przyszłym spadkobiercom właściciela przedsiębiorstwa rodzinnego jego otrzymania.

Protokół rodzinny może przewidywać również powołanie swoistych organów przedsiębiorstwa rodzinnego, jak np. rada krewnych (Junta de Parientes) — rodzaj forum rodzinnego, w którym mogą uczestniczyć

33 J. Egea Fernández, Protocolo familiar y pactos sucesorios..., s. 7.

${ }^{34}$ N. Alvarez Lata, Aspectos civiles de la empresa familiar: economía familiar y sucesión hereditaria, A Coruña 2011, s. 64.

${ }^{35}$ Umowy takie (zwane umowami testamentowymi - fr. contrats testamentaires) znane są niektórym systemom prawnym (np. większość stanów USA, Wielka Brytania, Norwegia, Dania, Islandia) i mają postać umów zobowiązujących do sporządzenia lub niesporządzenia testamentu (contract to make, or not to make, a will), nieodwołania lub powstrzymania się od zmiany testamentu (contract not to revoke and not to modify a will) — J. Pazdan, Umowy rodzinne o skutkach spadkowych..., s. 121. 
wszyscy członkowie rodziny, bez względu na to, czy są „współwłaścicielami” przedsiębiorstwa, czy też nie, i mogą wyrażać swoje uwagi, czy też rada rodzinna (Consejo de Familia), której zadaniem może być np. promowanie stosowania protokołu rodzinnego lub ustanawianie kryteriów rozwiązywania sporów ${ }^{36}$.

Wspomniany wyżej dekret królewski nr 171/2007 nie tylko zdefiniował pojęcie protokołu rodzinnego, lecz także w art. 3 i 4 uregulował kwestie ogłaszania protokołów ${ }^{37}$, które odpowiadają wprowadzonej aktem tym definicji, zarówno na stronie internetowej przedsiębiorstwa, jak i w rejestrze handlowym. Ogłoszenie protokołu jest możliwe, jeżeli spełnione są określone wymagania, jak ogłoszenie jednego protokołu odnoszącego się do danego przedsiębiorstwa (choć może on być przedmiotem różnych form ogłoszenia), w celu gwarancji bezpieczeństwa obrotu prawnego. Organem odpowiedzialnym za jego ogłoszenie w zgodzie z interesem przedsiębiorstwa/spółki jest organ zarządzający. Ogłoszenie takie musi być zgodne z przepisami o ochronie danych osobowych; należy także uzyskać wyraźną zgodę osób, których dane są ujęte w protokole.

Wprowadzono trzy rodzaje ogłoszenia protokołu, które mogą być traktowane alternatywnie lub kumulatywnie, aby zapewnić jak najlepsze dopasowanie rodzaju ogłoszenia do potrzeb każdego przedsiębiorstwa. I tak, może to być jedynie niewiążące osoby trzecie odnotowanie istnienia protokołu, z odniesieniem do jego danych identyfikacyjnych, ale nie do jego treści (art. 5 dekretu). Druga możliwość to złożenie protokołu lub jego części przy okazji prezentacji rocznych sprawozdań finansowych przez organ zarządzający przedsiębiorstwa (art. 6) - nie korzysta z domniemania jawności materialnej. Natomiast trzecia możliwość to rejestracja w formie aktu publicznego umów wspólników zawierających klauzule przyjęte w protokole (art. 7) — skuteczna wobec osób trzecich.

Jednym z celów ustawodawcy hiszpańskiego, wypowiedzianych między wierszami preambuły do dekretu dotyczącego protokołów rodzinnych, jest chęć stopniowego osłabiania zakazu zawierania umów dziedziczenia począwszy od wizji protokołu rodzinnego jako instrumentu, za pomocą którego założyciel przedsiębiorstwa rodzinnego zobowiąże się do wyznaczenia następcy.

${ }^{36}$ C. Gortázar Lorente, Derecho y empresa familiar: el protocolo y sus instrumentos de desarollo, https://dugi-doc.udg.edu/handle/10256/11162 [Dostęp: 20.09.2021 r.].

${ }^{37} \mathrm{~W}$ doktrynie pojawiają się głosy, czy aby publikowanie treści lub fragmentów protokołów rodzinnych nie jest zbędnym narażaniem przedsiębiorstw rodzinnych na ujawnianie ich strategii, reorganizacji zarządu lub planowanych inwestycji — tak: J. Egea Fernandez, Protocolo familiar y pactos sucesorios..., s. 4. 


\section{Heretament i pacte successori d'atribució particular ${ }^{38}$ jako przykłady umów dziedziczenia w prawie katalońskim}

Ustawodawca hiszpański w art. 669 h.k.c. zakazał sporządzania testamentów wspólnych ${ }^{39}$ (testamentos mancomunados - dopuszczalnych w Aragonii, Nawarze i Kraju Basków) ${ }^{40}$, natomiast w art. 1271 zd. 2 h.k.c. (w brzmieniu niezmienionym od 1889 r.) w sposób niefortunny sformułował zakaz zawierania umów dotyczących przyszłego spadku (herencia futura), z wyjątkiem umów, których celem jest dokonanie podziału majątku inter vivos, lub innych postanowień o podziale majątku, zgodnie z postanowieniami art. 1056 kodeksu cywilnego ${ }^{41}$. Kolejnym wyjątkiem, zgodnie $\mathrm{z}$ art. 1341 ust. 2 h.k.c., są darowizny na wypadek śmierci ${ }^{42}$, które mogą być dokonywane między przyszłymi małżonkami (krąg osób, które mogą zawrzeć taką umowę, nie obejmuje małżonków ani osób trzecich) ${ }^{43}$, wyłącznie w ramach umowy małżeńskiej.

${ }^{38}$ Częściej w literaturze prawniczej spotykane są hiszpańskie odpowiedniki nazw tych instytucji - heredamiento i pacto sucesorio de atribución particular.

${ }^{39}$ Szerzej na temat testamentów wspólnych: M. Margoński, Ważność testamentów wspólnych sporzadzanych przez obywateli polskich $w$ sprawach spadkowych z elementem transgranicznym, „Przegląd Sądowy” 2010, nr 10, s. 61-70.

40 Testamenty te również mogą być wskazane jako instytucje ułatwiające kształtowanie dziedziczenia przedsiębiorstw rodzinnych, szczególnie w zakresie, w jakim wchodzą one do majątku wspólnego małżonków.

${ }^{41}$ Artykuł ten w akapicie drugim stanowi m.in.: „Testator, który w trosce o zachowanie przedsiębiorstwa lub $\mathrm{w}$ interesie swojej rodziny chce zachować niepodzielną eksploatację gospodarczą lub zachować kontrolę nad spółką kapitałową, lub ich grupą, może skorzystać z uprawnienia przyznanego w niniejszym artykule, pod warunkiem wypłacenia w gotówce części spadku, którą testator nie może rozporządzać (legítima) pozostałym uprawnionym. W tym celu nie będzie konieczne, aby w majątku spadkowym znajdowała się wystarczająca ilość środków pieniężnych na wypłatę, przy czym możliwe będzie dokonanie wypłaty środków pieniężnych niepochodzących ze spadku i ustalenie przez spadkodawcę lub wyznaczonego przez niego księgowego odroczenia wypłaty, pod warunkiem, że okres ten nie przekracza pięciu lat liczonych od śmierci spadkodawcy; mogą również mieć zastosowanie wszelkie inne sposoby wygaśnięcia zobowiązań. Jeżeli forma zapłaty nie została ustalona, każdy spadkobierca może żądać przysługującej mu części spadku, którą testator nie może rozporządzać (legítima) z dóbr należących do majątku spadkowego. Postanowienia artykułu 843 i pierwszego ustępu artykułu 844 nie mają zastosowania do dokonanego w ten sposób podziału”.

${ }^{42}$ R. Krause, M. Margoński, Dziedziczenie po obywatelu Wenezueli zamieszkałym w Polsce: opinia prawna sporzadzona przez biegtych ad hoc z zakresu prawa obcego, „Problemy Prawa Prywatnego Międzynarodowego” 2014, T. 15, s. 102.

${ }_{43} \mathrm{P}$. Twardoch, Umowy matżeńskie $w$ prawie prywatnym międzynarodowym, C.H. Beck, Warszawa, 2019, s. 217. 
Niefortunne sformułowanie tego zakazu wzbudza wiele wątpliwości w doktrynie - czy dotyczy on spadku jako całości, czy odnosi się również do umów dotyczących poszczególnych przedmiotów, które mogłyby wejść w skład spadku ${ }^{44}$.

Sąd Najwyższy (Tribunal Supremo) w wyroku z dnia 22 lipca 1997 r. $^{45}$ wyraził pogląd zgodny z propozycjami zgłoszonymi w doktrynie, że zapis ten odnosi się jedynie do umów dotyczących całego spadku (universalidad de una herencia), nie dotyczy natomiast umów rozporządzających przedmiotami określonymi co do tożsamości i istniejącymi w momencie zawierania umowy. Linia orzecznicza budzi jednak sprzeciw przedstawicieli doktryny, którzy uważają, że brak uzasadnienia prawnego, które utrzymywałoby skuteczność zobowiązań dotyczących dziedziczenia bez względu na to, czy dotyczą one całego spadku, czy określonych jego przedmiotów ${ }^{46}$. Podkreślają oni, że umowa nie traci swojego charakteru czy też, że punktem decydującym o zakwalifikowaniu umowy jako dotyczącej dziedziczenia nie jest charakter jej przedmiotu - czy to uniwersalny, czy też syngularny. Co więcej, wyżej wspomniany zakaz został sformułowany o tyle niefortunnie, że w hiszpańskim systemie prawnym istnieją przepisy, które wymieniają umowę dotyczącą spadku jako formę powołania do dziedziczenia, tym samym przyjmując niejako jej funkcjonowanie w obrocie prawnym ${ }^{47}$.

Sam art. 1056 ust. 2 h.k.c. (do którego nawiązuje art. 1271 h.k.c.) został znowelizowany ustawą 7/2003 z dnia 1 kwietnia 2003 r. o spółce $\mathrm{z}$ ograniczoną odpowiedzialnością ${ }^{48} \mathrm{w}$ celu, jak to wskazuje preambuła, „umożliwienia uporządkowania relacji między członkami rodziny a sukcesją jednostki produkcyjnej, wyposażenia jej w instrumenty pozwalające zaplanować za życia przedsiębiorcy najwłaściwszą formę sukcesji przedsiębiorstwa we wszystkich jej możliwych konfiguracjach: korporacyjnej, indywidualnej itp." Reforma ta, zdaniem niektórych przed-

${ }^{44}$ F.J. Olmedo Castañeda, Prohibición de los pactos sucesorios..., s. 473.

45 STS 5240/1997.

${ }^{46}$ L. Díez-Picazo, A. Gullón, Sistema de Derecho civil, T. 4, Derecho de familia, Derecho de sucesiones, Tecnos, 2006, s. 467 - cytowane za X.M. Requeixo Souto, Pactos de atribución particular post mortem. Ámbito del articulo 1271, ap. 2 del Código civil, „Anuario de Derecho Civil” 2012, vol. 65, fasc. IV, s. 1747.

${ }_{47}$ Jest to m.in. art. 14 ustawy hipotecznej (Dekret z dnia 8 lutego 1946 r., BOE $\mathrm{N}^{\circ} 58$ z dnia 27 lutego 1946 r., BOE-A-1946-2453, tekst jedn. z dnia 3 czerwca 2021 r.), który stanowi m.in.: „tytułem powołania do spadku, dla celów Rejestru, jest testament, umowa dotycząca dziedziczenia [...]” oraz art. 4 ustawy 7/1998 z dnia 13 kwietnia o ogólnych warunkach zawierania umów z konsumentami (BOE N 89 z dnia 14 kwietnia 1998 r., BOE-A-1998-8789), który z zakresu zastosowania tejże ustawy wyłącza m.in. „umowy dotyczące dziedziczenia”.

${ }^{48} \mathrm{BOE} \mathrm{N}^{\circ} 79$ z dnia 2003 r., s. $12679-12689$. 
stawicieli doktryny, jest „oczywiście niewystarczająca i nie jest skonstruowana jako prawdziwa umowa dziedziczenia, która wyraźnie wyłączałaby ogólny zakaz z art. 1271 ust. 2 kodeksu cywilnego"49.

Dlatego też, jeśli dopuszczenie umów dziedziczenia zostałoby zharmonizowane odpowiednio z uzasadnionymi „minimalnymi” standardami, które pozwoliłyby na zaspokojenie rzeczywistych potrzeb spadkobierców koniecznych, brak powodu, aby ich nie dopuszczać.

Rozważana dopuszczalność umowy dziedziczenia jest ściśle związana z zachowaniem ciągłości przedsiębiorstw rodzinnych. Uważana jest za odpowiedni środek gwarantujący ich integralność i transfer międzypokoleniowy, co jest szczególnie użyteczne dla hiszpańskiej struktury przedsiębiorstw, biorąc pod uwagę znaczenie, jakie mają w niej przedsiębiorstwa rodzinne ${ }^{50}$.

Uwzględniając statystyki dotyczące przedsiębiorstw rodzinnych, w skali światowej można odnieść to również do innych krajów, w których ten typ przedsiębiorczości zajmuje szczególne miejsce (jak np. Polska). Dopuszczenie sukcesji umownej (sucesión contractual) ma szczególne znaczenie dla przedsiębiorstw rodzinnych w sytuacjach, gdy przedsiębiorstwo takie stanowi wspólność majątkową, a małżonkowie wyrażają chęć jednoczesnego, całkowitego lub częściowego, oraz nieodwołalnego przeniesienia własności na ich wspólnych spadkobierców.

Nie ma zatem powodów o charakterze gospodarczym lub legislacyjnym, ani jakiejkolwiek ogólnej zasady prawa, które mogłyby służyć jako ważna i przekonująca podstawa niedopuszczenia umów spadkowych w hiszpańskim prawie cywilnym. Stanowią one instrument prawny w służbie wolności obywatelskiej osób fizycznych, która pozwala im na ukształtowanie dziedziczenia ich majątku i jest szczególnie przydatna dla zapewnienia ciągłości przedsiębiorstw rodzinnych na rzecz najbardziej odpowiedniego i wykwalifikowanego do tego następcy ${ }^{51}$.

Ustawą 10/2008 z dnia 10 lipca $2008 \mathrm{r} .{ }^{52}$ ustawodawca kataloński wprowadził zmiany do IV Księgi kodeksu cywilnego Katalonii, dotyczące sukcesji umownej (successió contractual). Sam zresztą przyznał w preambule do tejże ustawy, że IV Księga kodeksu cywilnego reguluje kwestie umów dziedziczenia w sposób bardziej „otwarty i elastyczny”, nawiązując tym samym do kodeksu prawa spadkowego z dnia 30 grudnia $1991 \mathrm{r} \cdot{ }^{53}$, który wcześniej normował prawo spadkowe i wyraźnie odwo-

${ }_{49}$ Tak F.J. Olmedo Castañeda, Prohibición de los pactos sucesorios..., s. 457.

${ }_{50}$ Por. statystyki przedstawione w pkt. 2 niniejszego artykułu.

${ }^{51}$ F.J. Olmedo Castañeda, Prohibición de los pactos sucesorios..., s. 456.

${ }^{52} \mathrm{BOE} \mathrm{N}^{\circ} 190 \mathrm{z}$ dnia 7 sierpnia 2008 r., s. 33735-33788.

${ }_{53}$ Código de Sucesiones por causa de Muerte en el Derecho Civil de Cataluña-BOE $\mathrm{N}^{\circ} 50$ z dnia 27 lutego 1992 r., s. 6762-6789. 
ływał się do tradycji prawa rzymskiego co do zasady niedopuszczającego sukcesji umownej.

Jedną z podstawowych różnic między systemem hiszpańskim a katalońskim (po reformie z 2008 r.) jest dopuszczalność w Katalonii tzw. sukcesji umownej, z zastrzeżeniem różnicy pomiędzy umową powołania spadkobiercy (heretament) a umową dziedziczenia przysporzeń pod tytułem szczególnym (pacte successori d'atribució particular).

Kataloński heretament, zanim został po raz pierwszy wprowadzony przez współczesnego ustawodawcę w $1960 \mathrm{r.}^{54}$, od XIII w. był powszechnie stosowaną instytucją prawa zwyczajowego (derecho consuetudinario). W XIX w. instytucja ta wyszła naprzeciw oczekiwaniom wielkich, wielopokoleniowych rodów katalońskich, które w celu zaplanowania i zabezpieczenia przekazania kolejnym pokoleniom majątku rodzinnego (patrimoni familiar) włączały heretament do umów majątkowych małżeńskich, co pozwalało im osiągnąć bardzo ważny cel — zachowanie jedności casa (czyli majątku rodzinnego). Dzięki temu, że wywodzi się on z dawnego utrwalonego zwyczaju, jakże odległego od tradycji prawa rzymskiego, a także stopniowo „osadza” się w systemie prawnym o tradycjach romańskich, traktowany jest jako kontrapunkt dla rzymskich zasad prawa spadkowego, które stanowią fundamentalną część naszej kultury prawnej ${ }^{55}$.

Wyżej powołana ustawa $\mathrm{nr}$ 10/2008 ${ }^{56} \mathrm{w}$ art. $431-18 \mathrm{w}$ ust. 1 definiuje heretament jako „umowę powołania spadkobiercy, która w sposób nieodwołalny nadaje osobie lub osobom status spadkobiercy uniwersalnego", a ponadto zastrzega w ust. 2 , że status ten jest niezbywalny i nie podlega zabezpieczeniu (egzekucji).

Wcześniej zawieranie takich umów było dopuszczalne jedynie w ramach umów majątkowych małżeńskich (capitulaciones matrimoniales). Wspomniana reforma z 2008 r. „odłączyła” heretament od prawa rodzinnego i obecnie jest on traktowany jako pierwsze w kolejności, faworyzowane źródło powołania do spadku ${ }^{57}$.

Jedną z kolejnych innowacji wprowadzonych ustawą nr 10/2008 z dnia 10 lipca 2008 r. do IV Księgi k.k.c. jest umowa dziedzicze-

${ }^{54}$ Ustawa 40/1960 z dnia 21 lipca 1960 r., Compilación del Derecho Civil Especial de Cataluña, BOE N ${ }^{\circ}$ 175, z dnia 22 lipca 1960 r., s. 10215-10245 — kompilacja ta stanowiła rodzaj katalońskiego kodeksu cywilnego i określała m.in. aż 8 typów tejże instytucji.

55 C. Tort-Martorell, Sobre el heredamiento como excepción a los principios romanos de derecho sucesorio en el vigente código civil de Cataluña, „Fundamina. A Journal of Legal History" 2014, No si-2, s. 925.

${ }^{56} \mathrm{BOE} \mathrm{N}^{\circ} 190 \mathrm{z}$ dnia 7 sierpnia 2008 r., s. $33735-33788$.

${ }^{57}$ Art. 411-3 k.k.c. jako źródła powołania do spadku wymienia: 1) heretament, 2) testament i 3) ustawę. 
nia przysporzeń pod tytułem szczególnym (pacte successori d'atribució particular - art. 431-29 i 431-30 k.k.c.), która pozwala na dokonanie przysporzeń pod tytułem szczególnym przez osoby ją zawierające na „obraz i podobieństwo"58 zapisów w dziedziczeniu testamento$\mathrm{wym}^{59}$, bez konieczności powoływania $\mathrm{w}$ niej spadkobiercy ${ }^{60}$. Pozwala to na przeniesienie przedsiębiorstwa w całości i na jego ochronę przed rozdrobnieniem, jako że podobnie do heretament umowy te pozbawione są cechy charakterystycznej dla testamentów, a mianowicie odwołalności ${ }^{61}$.

Należy zaznaczyć, że art. 431-14 ust. 1 k.k.c. przewiduje wyjątki od zasady nieodwołalności ${ }^{62}$, dlatego też gdy głównym celem zawarcia takiej umowy była ochrona ciągłości działania przedsiębiorstwa i w umowie zostały zawarte postanowienia dotyczące zarządzania nim, w przypadku nieprzestrzegania tychże postanowień, możliwe będzie jednostronne odwołanie umowy czy też zawartego w umowie postanowienia obejmującego przedsiębiorstwo. Możliwość taka z pewnością stanowi swojego rodzaju „wentyl bezpieczeństwa” dla przedsiębiorcy przekazującego dorobek swojego życia i swoisty bodziec mobilizujący dla jego następcy.

W praktyce rozróżnienie pomiędzy wspomnianymi umowami dziedziczenia obejmującymi przysporzenia a umowami darowizny inter vivos $\mathrm{z}$ pewnością powoduje pewne trudności interpretacyjne. Inaczej

58 S. Navas Navarro, El pacto sucesorio de atribución particular en el Código civil de Cataluña, InDret 2009, $\mathrm{N}^{\circ} 2$, s. 4.

${ }_{59}$ Treść art. 431-30.5 k.k.c. wskazuje, że „w przypadku braku uzgodnień dotyczących poszczególnych przysporzeń zastosowanie mają przepisy dotyczące zapisów, które są zgodne z ich nieodwołalnym charakterem".

${ }^{60}$ Należy jednak w tym miejscu zaznaczyć, że już poprzedni Kodeks prawa spadkowego z 1991 r. (Código de Sucesiones por causa de Muerte en el Derecho Civil de Cataluña - BOE N 50 z dnia 27 lutego 1992 r., s. 6762-6789) wskazywał $\mathrm{w}$ art. 68 , że „w heretament mogą być przewidziane wszelkiego rodzaju warunki, ograniczenia, podstawienia, fideikomisy i zgodne z prawem przywrócenia do stanu poprzedniego, wyznaczanie zarządców i wykonawców oraz powierzanie, ogólnie rzecz biorąc, innym osobom wszelkiego rodzaju obciążeń lub funkcji, z takim samym zakresem, jak w testamentach", z taką jednak różnicą, że wraz z reformą z 2008 r. umowy te nabrały charakteru nieodwołalnego.

${ }^{61}$ Pojawiają się jednak głosy w doktrynie, które podają w wątpliwość, czy ustawodawca kataloński, formułując treść art. 431-30.5 k.k.c., nie pomylił nieodwołalności umowy dziedziczenia z nieodwołalnością przysporzenia w niej poczynionego. Tak: S. Navas Navarro, El pacto sucesorio..., s. 7. Niemniej jednak rozważania te wykraczają poza tematykę niniejszego artykułu.

62 a) z powodów wyraźnie uzgodnionych, b) z powodu niedopełnienia zobowiązań przez beneficjariusza, c) ze względu na niemożność zrealizowania celu, który był przedmiotem umowy lub któregokolwiek z jej postanowień, d) ze względu na zaistnienie istotnej, nieoczekiwanej i nieprzewidywalnej zmiany okoliczności leżących u jej podstaw. 
z umowami darowizny mortis causa, które nie charakteryzują się nieodwołalnością ${ }^{63}$.

Umowy obejmujące wspomniane przysporzenia mogą też wykazywać pewne podobieństwo do kodycyli ${ }^{64}$, niemniej jednak żadne $\mathrm{z}$ nich nie może być tytułem powołania do spadku, jako że, jak już wcześniej wspomniano, ustawodawca kataloński w sposób taksatywny wymienił źródła powołania do spadku: heretament, testament i ustawę.

Kolejna instytucja pomocna w planowaniu sukcesji to umowy dotyczące zrzeczenia się prawa do legítima $\mathrm{w}$ przypadkach, na jakie pozwala ustawodawca kataloński ${ }^{65}$. W sposób pośredni mogą one również ułatwiać przekazywanie przedsiębiorstw rodzinnych, o ile ich zawarcie doprowadza do uniknięcia rozdrobnienia spadku, a tym samym ochronę przedsiębiorstwa $^{66}$.

\section{Katalońskie umowy dziedziczenia na tle rozporządzenia 650/2012}

Ze względu na niejednolitość terytorialną hiszpańskiego prawa spadkowego, o której była już mowa, często dochodzi do poszukiwania rozwiązań kolizyjnoprawnych nie tylko na płaszczyźnie międzynarodowej, lecz również interregionalnej, o czym także była już mowa.

Podobnie jak w wielu innych krajach europejskich, istotne zmiany w prawie obowiązującym w Hiszpanii związane są z wejściem w życie rozporządzenia UE $\mathrm{nr} 650 / 2012^{67}$. W rozporządzeniu tym, w art. 3 ust. 1 pkt b, zamieszczona została definicja umowy dotyczącej spadku. Zgodnie z tym przepisem, „umowa dotycząca spadku oznacza umowę, $\mathrm{w}$ tym umowę wynikającą z testamentów wzajemnych, która odpłatnie

63 J. Egea Fernández, Protocolo familiar y pactos sucesorios..., s. 27.

${ }^{64}$ Á. Serrano de Nicolás, Pactos sucesorios de atribución particular: Su relación con otras instituciones sucesorias del propio Código Civil de Cataluña, „Revista General de Derecho Romano" 2011, N 16, https://www.iustel.com/v2/revistas/detalle_revista. asp?id_noticia $=410630 \& d=1$ [Dostęp: 20.09 .2021 r.].

${ }_{65}$ Omówiony w przyp. 22 art. $451-26$ k.k.c.

66 J. Egea Fernández, Protocolo familiar y pactos sucesorios..., s. 28.

${ }^{67}$ Rozporządzenie Parlamentu Europejskiego i Rady (UE) nr 650/2012 z dnia 4 lipca 2012 r. w sprawie jurysdykcji, prawa właściwego, uznawania i wykonywania orzeczeń, przyjmowania i wykonywania dokumentów urzędowych dotyczących dziedziczenia oraz w sprawie ustanowienia europejskiego poświadczenia spadkowego, Dz.Urz. UE L 201/107, 27.07.2013. 
lub nieodpłatnie tworzy, zmienia lub pozbawia praw do przyszłego spadku, lub przyszłych spadków, po co najmniej jednej osobie będącej stroną umowy”. Analizując termin „umowa dotycząca spadku”, należy również mieć na uwadze zakres zastosowania rozporządzenia, określony w art. 3 ust. 1 lit. $\mathrm{a}^{68}$.

Po dokonaniu analizy rozwiązań wprowadzonych przez ustawodawcę katalońskiego może pojawić się pytanie, czy umowy takie, jak umowa powołania spadkobiercy (heretament), czy umowa dziedziczenia przysporzeń pod tytułem szczególnym (pacte successori d'atribució particular), mieszczą się w zakresie pojęcia „umowa dotycząca spadku”, zdefiniowanego w art. 3 ust. 1 pkt b wspomnianego rozporządzenia. Należy na to pytanie udzielić odpowiedzi twierdzącej. Wcześniej (przed wspomnianą wyżej reformą z 2008 r.) zawieranie takich umów było dopuszczalne w Katalonii jedynie w ramach umów majątkowych małżeńskich, co mogłoby nasuwać wątpliwości co do ich kwalifikacji (jak ma to miejsce np. we Francji w przypadku klauzul przyznających pozostałemu przy życiu małżonkowi majątek wspólny w całości (clause d’attribution intégrale au conjoint survivant) ${ }^{69}$. Obecnie, przy uwzględnieniu zmian uprzednio wprowadzonych przez ustawodawcę katalońskiego, objęcie tych umów zakresem art. 3 ust. 1 pkt b rozporządzenia nie nasuwa wątpliwości.

\section{Podsumowanie}

Pożądana wydaje się całościowa reforma dziedziczenia przedsiębiorstw rodzinnych ze względu na ich znaczenie zarówno społeczne, jak i gospodarcze, tak w aspekcie czysto wewnętrznym, jak i międzynarodowym. Należy przy tym brać pod uwagę ich wkład w produkcję i generowanie zatrudnienia, a także ich wyjątkowość, która przejawia się w połączeniu typowej dla przedsiębiorczości zasady wydajności z cha-

68 „Dziedziczenie” oznacza dziedziczenie majątku po osobie zmarłej i obejmuje wszystkie formy przejścia składników majątku, praw i obowiązków na skutek śmierci, czy to na podstawie dobrowolnego rozrządzenia na wypadek śmierci, czy to w drodze dziedziczenia ustawowego.

69 A. Bonomi, The regulation on Matrimonial Property and Its Operation in Succession Cases - Its Interaction with the Succession Regulation and Its Impact on Nonparticipating Member States, „Problemy Prawa Prywatnego Międzynarodowego” 2020, T. 26, s. 79; P. Twardoch, Odgraniczenie statutów stosunków majattowych małżeńskich od innych statutów, „Problemy Prawa Prywatnego Międzynarodowego” 2015, T. 17, s. 97. 
rakterystyczną dla stosunków rodzinnych zasadą uczuciowości. W ostatnich latach jesteśmy świadkami wielu przemian społecznych - malejący wskaźnik urodzeń, większy stopień niezależności dzieci od rodziców (co można traktować jako wynik tendencji wyraźnie indywidualistycznych), zmiana modelu rodziny $\mathrm{z}$ wielopokoleniowej na nuklearną ${ }^{70}$. Wszystko to czyni ochronę przedsiębiorstwa rodzinnego jeszcze bardziej skomplikowaną. Dlatego pojawiły się sugestie ${ }^{71}$, by w celu ochrony przedsiębiorstwa rodzinnego, jako istotnej części struktury gospodarczej, wzmocnić rodzinę jako pierwszą i zarazem podstawową komórkę społeczną.

Jedną z propozycji, która pojawiła się na arenie międzynarodowej i miała na celu ułatwienie planowania sukcesji przedsiębiorstw (w tym także rodzinnych), było wprowadzenie do przygotowywanego rozporządzenia spadkowego jako jednej z możliwości wyboru prawa właściwego w sprawach spadkowych - prawa siedziby przedsiębiorstwa. Jak twierdzi A. Davì ${ }^{72}$, jeden $\mathrm{z}$ autorów tejże propozycji, ułatwiłoby to ochronę przedsiębiorstwa ze względu na daleko sięgające różnice w systemach prawnych poszczególnych państw (dotyczące zarówno kwestii rezerwy/zachowku, jak też dopuszczalności zawierania umów dziedziczenia). Propozycja ta nie weszła do rozporządzenia nr 650/2012. Przepis art. 22 tego rozporządzenia przewiduje jedynie wybór prawa państwa, którego obywatelem jest spadkodawca w chwili wyboru lub w chwili śmierci. Nasuwa się pytanie, czy nie należałoby do tej propozycji powrócić. Z kolei ustawodawcy krajowi państw członkowskich Unii Europejskiej powinni, wykorzystując doświadczenia partnerów, wzbogacić wachlarz instrumentów wspomagających przedsiębiorców rodzinnych $\mathrm{w}$ tej jakże skomplikowanej dla nich materii, jaką jest sukcesja przedsiębiorstwa.

Także polski ustawodawca nie powinien ustawać w poszukiwaniu instytucji, które wspomogą przedsiębiorców w procesie planowania dziedziczenia. Dotychczasowe rozważania skłaniają do wniosku, że zarówno wprowadzona przez ustawodawcę polskiego instytucja zarządu sukcesyjnego, jak i zapis windykacyjny w postaci wprowadzonej w 2011 r. nie

${ }^{70}$ A. Kwak, Od rodziny nuklearnej Talcotta Parsonsa do wielości form życia rodzinnego wspótcześnie, „Roczniki Nauk Społecznych” 2019, nr 4, s. 129.

${ }^{71}$ F.J. Olmedo Castañeda, La empresa familiar en el Derecho español: necesidad de una regulación jurídica, El Notario del Siglo XXI, Revista 84, https://www.elnotario.es/ hemeroteca/revista-84/9281-la-empresa-familiar-en-el-derecho-espanol-necesidad-deuna-regulacion-juridica [Dostęp: 20.09.2021 r.].

72 A. Davì, L'autonomie de la volonté en droit international privé des successions dans la perspective d'une future Réglamentation Européenne, in: Les successions internationales dans l'UE - Perspectives pour une harmonisation, Wüzburg, DNotI, 2004, s. 396. 
gwarantują należytej ochrony przedsiębiorstw rodzinnych w toku zmian pokoleniowych, zarówno w aspekcie strukturalnym, podmiotowym, jak i ekonomicznym.

Uwzględniając przytoczone wyżej argumenty, można by rozpocząć dyskusję nad wprowadzeniem w Polsce nowych instrumentów prawnych, które, przy zachowaniu specyfiki polskiego prawa spadkowego i charakterystycznych dla niego instytucji, w odpowiedni sposób zabezpieczałyby losy przedsiębiorstw rodzinnych podlegających zmianom pokoleniowym. Wydaje się, że interesującą propozycję stanowić mogłaby umowa dziedziczenia w przedstawionej powyżej postaci przysporzeń pod tytułem szczególnym (pacte successori d'atribució particular). Zdaje się ona zapewniać odpowiednią ochronę przechodzącemu zmiany pokoleniowe przedsiębiorstwu rodzinnemu, pozwalając na zachowaniejego integralności, uniknięcie nieracjonalnych podziałów, a nadto możliwość określenia dysponującego odpowiednimi kwalifikacjami „następcy”73, zgodnie z wolą przyszłego spadkobiercy ${ }^{74}$. Wprowadzenie takiej regulacji wiązałoby się nieuchronnie ze złagodzeniem wynikającego z art. 1047 k.c. zakazu zawierania umów o spadek po osobie żyjącej.

Protokół rodzinny, opisany w tym artykule, także mógłby znaleźć odpowiednik w polskim porządku prawnym w formie dostosowanej do polskich realiów. Jest to instytucja oryginalna i nieznana wcześniej polskiemu porządkowi prawnemu, niemniej jednak wprowadzony do naszego prawa odpowiednik hiszpańskiego protokołu rodzinnego mógłby stanowić jeden ze sposobów wsparcia w najtrudniejszych momentach procesu zmian pokoleniowych (nie tylko w przypadku śmierci przedsiębiorcy, lecz także ciężkiej choroby czy tymczasowej niemożności zarządzania przedsiębiorstwem), a przede wszystkim wspomóc przedsiębiorstwa rodzinne w układaniu zarówno stosunków wewnętrznych, jak i zewnętrznych z podmiotami trzecimi. Instrument taki byłby potrzebny szczególnie w przypadku przedsiębiorstw rodzinnych nieobjętych zakresem zastosowania instytucji zarządu sukcesyjnego.

Podsumowując dotychczasowe rozważania, należy stwierdzić, że dostępność licznych odpowiednio skonstruowanych instrumentów prawnych może być traktowana jedynie jako zaleta systemu prawnego, pozwalająca na dopasowanie i przystosowanie tychże instrumentów do po-

${ }^{73} \mathrm{Z}$ uwzględnieniem wprowadzonych w katalońskim prawie spadkowym wyjątków od zasady nieodwołalności opisanych wyżej, stanowiących niejako wentyl bezpieczeństwa dla przedsiębiorcy przekazującego dorobek swojego życia i swoisty bodziec mobilizujący dla jego następcy.

${ }^{74}$ Heretament również wydaje się ciekawą propozycją, aczkolwiek z pewnością przez wielu przedstawicieli doktryny uważana będzie za zbyt rewolucyjną, jako że stanowi ona odrębny od testamentu tytuł powołania do spadku. 
trzeb danego przedsiębiorcy i zaspokojenie jednego z głównych interesów państwa, jakim jest zapewnienie kontynuacji działalności gospodarczej.

\section{Bibliografia}

Alvarez Lata N., Aspectos civiles de la empresa familiar: economía familiar y sucesión hereditaria, Netbiblo, A Coruña, 2011.

Bieluk J., Zarzqdca sukcesyjny - nowa instytucja w polskim prawie spadkowym, „Białostockie Studia Prawnicze” 2017, T. 22, nr 4, s. 47-57.

Blajer P., Umowa o spadek jako narzędzie zmian generacyjnych $w$ rolnictwie na przyktadzie wtoskiej instytucji „patto di famiglia”, „Kwartalnik Prawa Prywatnego" 2011, z. 2, s. 435-506.

Blicharz R., Ustanowienie zarzadu sukcesyjnego przedsiębiorstwem osoby fizycznej po jej śmierci, w: Prawo handlowe. Między teoria, praktyka a orzecznictwem. Ksiega jubileuszowa dedykowana Profesorowi Januszowi A. Strzepce, red. P. Pinior, P. Relidzyński, W. Wyrzykowski, E. Zielińska, M. Żaba, C.H. Beck, Warszawa, 2019, https://sip.legalis.pl/document-full.seam?documentId=mjxw62zogi3damrtgmydkni.

Bonomi A., The regulation on Matrimonial Property and Its Operation in Succession Cases - Its Interaction with the Succession Regulation and Its Impact on Non-participating Member States, „Problemy Prawa Prywatnego Międzynarodowego" 2020, T. 26, s. 71-89.

Caccavale C., Divieto dei patti successori ed attualità degli interessi tutelati. Appunti per uno studio sul Patto di famiglia: profili strutturali e funzionali della fattispecie, https://elibrary.fondazionenotariato.it/articolo.asp?ar$\mathrm{t}=02 / 0203 \& \mathrm{mn}=3$.

Caló E., El proyecto de Reglamento de la Unión Europea sobre la ley aplicable a las sucesiones: lo que no se ha dicho, InDret 2010, No 3, s. 2-10.

Cámara Lapuente S., New developments in the Spanish Law of Succession, InDret $2007, \mathrm{~N}^{\circ} 4$, s. 2-49.

Carrascosa González J., El Reglamento Sucesorio Europeo 650/2012 de 4 Julio 2012: análisis crítico, Rapid Centro, Murcia, 2019.

Davì A., L'autonomie de la volonté en droit international privé des successions dans la perspective d'une future Réglamentation Européenne, in: Les successions internationales dans l'UE - Perspectives pour une harmonisation, Wüzburg, DNotI, 2004, s. 387-415.

Egea Fernández J., Protocolo familiar y pactos sucesorios. La proyectada reforma de los heredamientos, InDret 2007, $\mathrm{N}^{\circ} 3$, s. 2-36.

Fernández-Sancho Tahoces A.S., La sucesión en la empresa familiar: el protocolo familiar y su publicidad registral, „Revista Aranzadi de derecho patrimonial" 2009, Nº 23, s. 287-306. 
Ferré-André S., Le droit français du mandat à effet posthume, une innovation attendue de la loi du 23 juin 2006, „La Revue du Notariat” [Montréal] 2009, vol. 111, s. 381-391.

Gortázar Lorente C., Derecho y empresa familiar: el protocolo y sus instrumentos de desarollo, https://dugi-doc.udg.edu/handle/10256/11162.

Górniak K., Mandat na wypadek śmierci w prawie francuskim, „Kwartalnik Prawa Prywatnego" 2019, z. 4, s. 919-939.

Guillame F., Papeil A.-S., Transmission d'une entreprise familiale à un descendant: essai comparatif Suisse-France, „Semaine judiciaire” 2009, N ${ }^{\circ}$, s. $33-73$.

Ieva M., Il patto di famiglia, in: P. Rescigno, M. Ieva, Trattato breve delle successioni e donazioni, CEDAM, 2010, s. 317-347.

Krause R., Margoński M., Dziedziczenie po obywatelu Wenezueli zamieszkatym w Polsce: opinia prawna sporzadzona przez biegtych „ad hoc” z zakresu prawa obcego, „Problemy Prawa Prywatnego Międzynarodowego” 2014, T. 15, s. $87-104$.

Krysa J., Niejednolitość terytorialna prawa hiszpańskiego a prawo prywatne międzynarodowe, „Problemy Prawa Prywatnego Międzynarodowego” 2014, T. 14 , s. $9-50$.

Kwak A., Od rodziny nuklearnej Talcotta Parsonsa do wielości form życia rodzinnego współcześnie, „Roczniki Nauk Społecznych” 2019, nr 4, s. 129 146.

Margoński M., Ważność testamentów wspólnych sporzadzanych przez obywateli polskich $w$ sprawach spadkowych z elementem transgranicznym, „Przegląd Sądowy" 2010, nr 10, s. 61-70.

Navas Navarro S., El pacto sucesorio de atribución particular en el Código civil de Cataluña, InDret 2009, No 2, s. 2-35.

Olmedo Castañeda F.J., La empresa familiar en el Derecho español: necesidad de una regulación jurídica, „El Notario del Siglo XXI” - Revista 84, https:// www.elnotario.es/hemeroteca/revista-84/9281-la-empresa-familiar-en-elderecho-espanol-necesidad-de-una-regulacion-juridica.

Olmedo Castañeda F.J., Prohibición de los pactos sucesorios en el Derecho común: cuestionamento de su ratio legis. Propuesta para su admisibilidad, „Anuario de Derecho Civil” 2019, vol. 72, fasc. II, s. 447-483.

Pazdan J., Umowy dotyczace spadku $w$ rozporzadzeniu spadkowym Unii Europejskiej, C.H. Beck, Warszawa, 2018.

Pazdan J., Umowy dziedziczenia $w$ Rozporzadzeniu Unii Europejskiej z 2012 r. w sprawach spadkowych, w: Rozprawy cywilistyczne. Ksiega pamiatkowa dedykowana Profesorowi Edwardowi Drozdowi, red. M. Pecyna, J. Pisuliński, M. Podrecka, LexisNexis, Warszawa, 2013.

Pazdan J., Umowy rodzinne o skutkach spadkowych na tle rozporzadzenia Nr 650/2012, w: Kolizyjne i procesowe aspekty prawa rodzinnego, red. J. Gołaczyński, W. Popiołek, C.H. Beck, Warszawa, 2019, s. 117-125.

Pazdan M., O rozgraniczaniu statutów $i$ wsysaniu regulacji prawnej (na przykładzie prawa stosowanego do oceny różnych aspektów powołania $i$ funk- 
cjonowania wykonawcy testamentu $i$ zarzadcy sukcesyjnego przedsiębiorstwem), „Problemy Prawa Prywatnego Międzynarodowego” 2020, T. 27, s. $159-177$.

Pazdan M., Umowy dziedziczenia w polskim prawie prywatnym międzynarodowym, „Studia Iuridica Silesiana” 1979, nr 5, s. 151-168.

Pazdan M., Zarzad sukcesyjny — aspekty kolizyjnoprawne, w: Prawo handlowe. Między teoria, praktyka a orzecznictwem. Ksiega jubileuszowa dedykowana Profesorowi Januszowi A. Strzępce, red. P. Pinior, P. Relidzyński, W. Wyrzykowski, E. Zielińska, M. Żaba, C.H. Beck, Warszawa, 2019, https://sip. legalis.pl/document-full.seam?documentId=mjxw62zogi3damrtgmydqna.

Pazdan M., Zarzadca sukcesyjny a wykonawca testamentu, w: „Ius est ars boni et aequi". Księga pamiatkowa dedykowana Profesorowi Józefowi Frackowiakowi, red. A. Dańko-Roesler, M. Leśniak, M. Skory, B. Sołtys, Wolters Kluwer, Wrocław, 2018, s. 885-894.

Pazdan M., Zachariasiewicz M., Highlights and Pitfalls of the EU Succession Regulation, „Problemy Prawa Prywatnego Międzynarodowego” 2020, T. 26, s. $125-187$.

Petrelli G., La nuova disciplina del patto di famiglia, „Rivista del Notariato” 2006, N ${ }^{\circ}$ 60, s. 401-466.

Pisuliński J., Pojęcie umowy dziedziczenia $w$ prawie prywatnym międzynarodowym oraz umowy dotyczqcej spadku w rozporzadzeniu spadkowym, w: Nowe europejskie prawo spadkowe, red. M. Pazdan, J. Górecki, Wolters Kluwer, Warszawa, 2015, s. 144-167.

Requeixo Souto X.M., Pactos de atribución particular post mortem. Ámbito del articulo 1271, ap. 2 del Código civil, „Anuario de Derecho Civil” 2012, vol. 65 , fasc. IV, s. $1745-1781$.

Rodríguez-Uría Suárez I., La ley aplicable a los pactos sucesorios, Universidade de Santiago de Compostela, 2014.

Rodríguez-Uría Suárez I., La ley aplicable a las sucesiones mortis causa en el Reglamento (UE) 650/2012, InDret 2013, No 2, s. 2-58.

Serrano de Nicolás Á., Pactos sucesorios de atribución particular: Su relación con otras istituciones sucesorias del propio Código Civil de Cataluña, „Revista General de Derecho Romano” 2011, No 16, https://www.iustel.com/ $\mathrm{v} 2 /$ revistas/detalle_revista.asp?id_noticia $=410630 \& \mathrm{~d}=1$.

Tort-Martorell C., Sobre el heredamiento como excepción a los principios romanos de derecho sucesorio en el vigente código civil de Cataluña, „Fundamina. A Journal of Legal History" 2014, Nº si-2, s. 925-937.

Twardoch P., Odgraniczenie statutów stosunków majatkowych matżeńskich od innych statutów, „Problemy Prawa Prywatnego Międzynarodowego” 2015, T. 17, s. 81-102.

Twardoch P., Rozgraniczenie statutu spadkowego $i$ prawa właściwego dla matżeńskiego ustroju majatkowego na tle rozporzadzenia spadkowego $i$ regulacji krajowych dotyczacych stosunków majatkowych między matżonkami oraz projektu rozporzadzenia $w$ sprawie matżeńskich ustrojów majatkowych, w: Nowe europejskie prawo spadkowe, 
red. M. Pazdan, J. Górecki, Wolters Kluwer, Warszawa, 2015, s. 228243.

Twardoch P., Umowy matżeńskie $w$ prawie prywatnym międzynarodowym, C.H. Beck, Warszawa, 2019. 